\title{
CATCH PATTERNS OF THE GERMAN BALTIC SEA TRAWL FLEET TARGETING DEMERSAL SPECIES BETWEEN 2006 AND 2009
}

\author{
Wolfgang N. PROBST ${ }^{1,2^{*}}$, Ulrich BERTH ${ }^{1}$, Daniel STEPPUTTIS ${ }^{1}$, Cornelius HAMMER ${ }^{1}$ \\ ${ }^{1}$ Johann Heinrich von Thünen-Institute of Baltic Sea Fisheries, Alter Hafen Süd 2, 18069 Rostock, Germany \\ ${ }^{2}$ Johann Heinrich von Thünen-Institute of Sea Fisheries, Palmaille 9, 22769 Hamburg, Germany
}

Probst W.N., Berth U., Stepputtis D., Hammer C. 2011. Catch patterns of the German Baltic Sea trawl fleet targeting demersal species between 2006 and 2009. Acta Ichthyol. Piscat. 41 (4): 315-325.

\begin{abstract}
Background. The data collection of commercial fisheries has been formalized by the EU data collection framework (DCF). Besides gaining relevant information to fisheries management under the Common Fisheries Policy, the data of the DCF will gain importance in assessing the impacts of fishing on the ecosystem of the Baltic Sea.

Materials and methods. The catch of the demersal German Baltic Sea trawl fleet between 2006 and 2009 was sampled by on-board observers to investigate the temporal and spatial patterns in catch composition.

Results. There was a general increment in tow duration, landing weights, and discard weights from west to east. The most important species by catch weight was cod, for which highest catches were obtained during spring in ICES subdivision 25. Single hauls exceeded $25 \mathrm{~h}$ and caught more than $9900 \mathrm{~kg}$ of cod. On average, about 5\%, $13 \%$, and $20 \%$ and of the captured cod, flounder, and dab, respectively, were discarded.

Conclusion. The presently reported study provides a benchmark for the German Baltic Fisheries that can be used for assessment of new management regulations and/or new marine policies. A comprehensive documentation of the spatial and temporal catch distribution of the German Baltic demersal trawl fleet, prior to the implementation of marine spatial planning measures such as marine protected areas or offshore wind farms, should help to evaluate the implications of intensifying spatial use on the fishing industry.
\end{abstract}

Keywords: commercial fisheries, landings, discard, spatial fishing distribution, data collection framework, Baltic cod

\section{INTRODUCTION}

Fisheries science has always been driven by the exploitation of marine living resources. To understand the impacts of fishing on fish stocks and the marine ecosystems, data from commercial fishing operations are required. Consequently the sampling of commercial fisheries has a long tradition in fisheries science (Jennings et al. 2001). The fisheries derived data is used for stock assessment, assessing the impacts of fishing on marine habitats, by-catch species and exploited species, but also for the evaluation of policy scenarios and their influences on fishing fleets (Stelzenmüller et al. 2010, Fock et al. 2011).

Information on the composition of landings and catches are commonly gained by harbour sampling or on-board observers (observers-at-sea) (Stratoudakis et al. 1998, Cotter and Pilling 2007, King 2007, Benoit and Allard 2009, Ulleweit et al. 2010). The sampled catches are used to raise the known landing weights from logbook entries to total catch-numbers-at-age, which are essential input data for stock assessments. However, to account for discards, which are not reported in logbooks, the catch composition of commercial vessels has to be sampled at sea.
Traditionally the collection of samples from the commercial fishing fleet has been conducted on national basis. In 2002, the European Union (EU) implemented the data collection framework (DCF, formally known as DCR) which harmonizes the national sampling of fishing fleets between the EU members by providing financial support and a regional coordination framework (Anonymous 2004, Stransky et al. 2008). The DCF obliges the member states to sample their most important fisheries ranked by landing mass, value, and effort. Depending on the type of fisheries and expected discard mass, the DCF demands the member states to place observers on board of commercial fishing vessels. The on-board observers are responsible for recording characteristics of the vessel and the gear, the catch composition, and the length spectra of the most important target- and by-catch species.

This study analyses catch composition by weight of the German Baltic Sea demersal trawl fleet using the data gathered from 2006 until 2009 by on-board observers, authorised by the Data Collection Framework (DCF). The principal targets of the German Baltic Sea demersal trawl net fleet are Baltic cod and flatfish. The fleet consists of

\footnotetext{
* Correspondence: Dr. Wolfgang N. Probst, Johann Heinrich von Thünen-Institut, Institut für Seefischerei, Palmaille 9, 22767 Hamburg, Germany, phone: ++49 (0)40 38905202, fax: +49 (0)40 389905263, e-mail: nikolaus.probst@vti.bund.de.
} 
about 90 vessels between 8 and $26 \mathrm{~m}$ in length. Since 2006, it is mandatory to use one of two possible selective codends: BACOMA and T90. The BACOMA codend has an escape window made of knotless, square meshed netting in the upper panel, whereas the T90 consists of diamond mesh netting which is oriented perpendicularly to the long axis of the gear to keep meshes open (Suuronen et al. 2007, Wienbeck et al. 2011). Between 2006 and 2009 the legal mesh opening for both codends was $110 \mathrm{~mm}$. The period between 2006 and 2009 was therefore chosen, in the presently reported study, to characterize the fishing patterns of the German demersal trawl fleet during a phase of consistent mesh size regulation. The minimum landing size (MLS) in ICES subdivisions (SD) 22-25 (western Baltic Sea and east of Bornholm) is $38 \mathrm{~cm}$ for Atlantic cod, $23 \mathrm{~cm}$ for European flounder, $25 \mathrm{~cm}$ for plaice, and $30 \mathrm{~cm}$ for turbot (Anonymous 2005). Dab has no minimum landing size.

\section{MATERIALS AND METHODS}

Data source. The catch composition was sampled by on-board observers who separated the catches by landings and discard. For this study, data from the German Baltic DCF in the period between 2006 and 2009 were analyzed resulting in a data set of 372 sampled hauls containing catch weights of the five demersal target- and by-catch species: Atlantic cod, Gadus morhua L.; European flounder, Platichthys flesus (L.); European plaice, Pleuronectes platessa L.; common dab, Limanda limanda (L.), and turbot Scophthalmus maximus (L.). The number of sampled cruises, vessels, and hauls are given in Table 1.

The sampling coverage as percentage of sampled landing weight indicates the mean sampling coverage across all years and all five taxa amounting to $1.1 \%$ (Table 2).

The declared landing weight of the main target species in a given haul was obtained from the logbook and used

Table 1

Overview of at-sea sampling intensity between 2006 and 2009

\begin{tabular}{lccrl}
\hline \multirow{2}{*}{ Year } & \multicolumn{4}{c}{ Number of sampled items } \\
\cline { 2 - 5 } & Vessels & Cruises & Hauls & Gear classes used \\
\hline 2006 & 8 & 18 & 62 & OTB, PTB, TTB \\
2007 & 13 & 27 & 100 & OTB, OTM, PTB, TTB \\
2008 & 14 & 30 & 89 & OTB, OTM, PTB, TTB \\
2009 & 14 & 44 & 121 & OTB, OTM, PTB, TTB \\
\hline Total & 26 & 119 & 372 & \\
\hline
\end{tabular}

$\mathrm{OTB}=$ otter trawl bottom, OTM = otter trawl midwater, PTB = pair trawl bottom, TTB = twin trawl bottom; Total refers to the total number of observed vessels, trips and hauls; Note, that the same vessels were observed in different years so that the total number of observed vessels is not equal to the sum of observed vessels per year!

Table 2

Sampled and landed weights of the five dominant demersal species caught by the German trawl fleet between 2006 and 2009

\begin{tabular}{|c|c|c|c|c|c|}
\hline Year & Species & $\begin{array}{c}\text { Landing weight sampled } \\
{[\mathrm{t}]}\end{array}$ & $\begin{array}{c}\text { Total weight landed } \\
{[\mathrm{t}]}\end{array}$ & $\%$ sampled & $\begin{array}{l}\text { Mean species-specific } \\
\text { discard rate }[\% \pm \mathrm{SD}]\end{array}$ \\
\hline \multirow{5}{*}{2006} & Cod & 100.63 & 9551 & 1.05 & $7.66 \pm 6.80$ \\
\hline & Flounder & 17.23 & 1015 & 1.70 & $18.66 \pm 25.72$ \\
\hline & Plaice & 3.60 & 231 & 1.56 & $10.32 \pm 24.29$ \\
\hline & $\mathrm{Dab}$ & 2.93 & 529 & 0.55 & $43.39 \pm 43.36$ \\
\hline & Turbot & 0.41 & 65 & 0.63 & $3.42 \pm 17.84$ \\
\hline \multirow{5}{*}{2007} & Cod & 104.66 & 8331 & 1.26 & $7.55 \pm 7.80$ \\
\hline & Flounder & 20.82 & 3055 & 0.68 & $18.51 \pm 27.29$ \\
\hline & Plaice & 1.55 & 220 & 0.70 & $20.92 \pm 33.35$ \\
\hline & Dab & 2.47 & 490 & 0.50 & $26.44 \pm 39.91$ \\
\hline & Turbot & 0.64 & 56 & 1.14 & $0.00 \pm 0.00$ \\
\hline \multirow{5}{*}{2008} & Cod & 158.36 & 7830 & 2.02 & $5.48 \pm 4.72$ \\
\hline & Flounder & 31.65 & 2473 & 1.28 & $58.57 \pm 45.71$ \\
\hline & Plaice & 2.04 & 251 & 0.81 & $9.32 \pm 20.73$ \\
\hline & $\mathrm{Dab}$ & 0.87 & 540 & 0.16 & $62.25 \pm 47.49$ \\
\hline & Turbot & 0.23 & 54 & 0.43 & $0.95 \pm 8.01$ \\
\hline \multirow{5}{*}{2009} & Cod & 210.03 & 7685 & 2.73 & $9.99 \pm 10.86$ \\
\hline & Flounder & 25.52 & 1731 & 1.47 & $37.82 \pm 41.35$ \\
\hline & Plaice & 6.85 & 314 & 2.18 & $6.89 \pm 22.62$ \\
\hline & Dab & 1.60 & 619 & 0.26 & $52.26 \pm 48.70$ \\
\hline & Turbot & 0.69 & 84 & 0.82 & $0.88 \pm 9.10$ \\
\hline
\end{tabular}

OTB = otter trawl bottom, OTM = otter trawl midwater, PTB = pair trawl bottom, TTB = twin trawl bottom; Total refers to the total number of observed vessels, trips and hauls; Note, that the same vessels were observed in different years so that the total number of observed vessels is not equal to the sum of observed vessels per year! 
to raise the sample weights of catch components (landings and discards) of all species by the ratio of declared landing weight/sampled landing weight of the target species. In cases of small catches with less than approximately 500 $\mathrm{kg}$ weight, the entire catch was sampled and weighed. Between 2006 and 2009 it was not possible to randomly select the sampled vessels because the number of accessible vessels was small and the compliance of some vessel captains was lacking.

Statistical analysis. The catch per unit effort (CPUE) was calculated as the weight of the catch divided by the tow duration and is expressed as $\mathrm{kg} \cdot \mathrm{h}^{-1}$. The relative discard rate is the proportion of discard weight of a species in the total catch weight given as percent. Species-specific discard rates were calculated as the discarded proportion of the total caught weight of a species. The relative discard rates of the median catch were calculated as the percentage of the total sum of median discard weights by species. For a comparison of CPUE and discard rates, non-parametric Kruskal-Wallis ANOVAs were performed with gear, quarter, year, and subdivisions as factors. The difference between medians within single factor groups were performed by pair-wise Mann-Whitney $U$ tests with corrected significance thresholds of 0.05 divided by the number of pair wise comparisons per factor.

The catch composition by weight of each haul was ordinated by non-metric multidimensional scaling (nMDS) using the vegan package under R2.12.0 (Anonymous 2008a, Oksanen et al. 2011). NMDS is a non-parametric ordination method using distance ranks instead of raw distances thus being unaffected by differences in dimension and non-normality (Minchin 1987, Clarke and Warwick 2001, Mehner et al. 2005). The catch composition of the five most abundant target species by discard and landing weights was scaled using the metaMDS function of the vegan package by Bray-Curtis dissimilarities. MetaMDS performs nMDS ordination with several random starts to avoid getting trapped in local minima and finds a stable solution with minimum stress. Because in some hauls the catch composition was equal, the Bray-Curtis similarity was zero between these samples. The metaMDS function cannot ordinate zero-dissimilarities and thus the trip identification number ranging from $1 / 12$ to 1 was added to the community data matrix thus making the data of each haul unique while reducing the impact of the identifier. The nMDS ordination of catch composition was overlaid by the ordination of the factor centroids with year, quarter, vessel length, ICES sub division, geographical longitude and latitude, used gear type, and tow duration by the envfit function of the vegan package. Envfit fits vectors for numeric variables to the ordination space where they have the highest correlation with the ordination configuration and averages the ordination scores for factor levels of nominal variables. For two hauls no position data were available and these hauls were deleted from the ordination matrix.

\section{RESULTS}

Spatial and temporal distribution of the sampled

fleet. Between 2006 and 2009 the German demersal Baltic trawl fleet used four gear types for targeting demersal fish, namely bottom otter trawls (OTB), otter board mid water trawls (OTM), pair bottom trawls where two vessels tow one net (PTB) and twin bottom trawls (TTB) where two nets are towed by one vessel. OTM is only used in sub division (SD) 25, PTB is not used east of $14.5^{\circ} \mathrm{E}$ longitude, OTB and TTB are used throughout the western and central Baltic Sea (Fig. 1a). The sampled fishing activities occurred in all SD during the first quarter, and clustered in SD 25 in the second quarter (Fig. 1b). In the third and fourth quarter fishing was sampled mostly in SD 24. The tow duration was longest in SD 25 with tows lasting $1750 \mathrm{~min}$ (more than $29 \mathrm{~h}$ ), shorter in SD 24 and always less than 750 min in SD 22 (Fig. 1c). The distribution of the sampled hauls between years does not indicate any annual bias (Fig. 1d). According to the tow duration, the total landing weights were highest in SD 25 with peak landings of more than $9000 \mathrm{~kg}$ per haul (Fig. 1e). Total landings per haul reached up to $6384 \mathrm{~kg}$ in SD 24, whereas in SD 22 no landing exceeding $4000 \mathrm{~kg}$ was achieved. The spatial discard pattern deviates from the east-west gradient observed for tow duration and landing weight. The highest discard weight per haul occurred in SD 24 with $4736 \mathrm{~kg}$, followed by $4143 \mathrm{~kg}$ in SD 25, whereas in SD 22 the maximum discard weight per haul was $655 \mathrm{~kg}$ (Fig. 1f).

Observed patterns in CPUE and discard rates. Cod was the main species in the catch of the German demersal trawl fleet with a median CPUE of $183.62 \mathrm{~kg} \cdot \mathrm{h}^{-1}$, followed by flounder with a median CPUE of $14.79 \mathrm{~kg} \cdot \mathrm{h}^{-1}$. The median CPUE of other flatfish was lower than $3.0 \mathrm{~kg} \cdot \mathrm{h}^{-1}$ (plaice median CPUE $=2.04 \mathrm{~kg} \cdot \mathrm{h}^{-1}$, dab median CPUE $=0.86 \mathrm{~kg} \cdot \mathrm{h}^{-1}$, and turbot median CPUE $=0.00 \mathrm{~kg} \cdot \mathrm{h}^{-1}$. The catch per unit effort (CPUE) was highest for cod in the OTM fisheries, followed by PTB and TTB and was lowest with OTB gear (Table 3). For flatfish, CPUE were lowest with OTM. The highest CPUE of cod was observed in quarter two, and lowest cod CPUE were obtained in quarter three and four (Table 3). The CPUE of flatfishes was highest in quarter one followed by quarter four. Compared by year, the CPUE of cod was smaller in 2007 than in the other years (Table 3). The CPUE of flounder was highest in 2008. The CPUE of other flatfishes was highest in 2006. The CPUE of cod was highest in SD 25 and about half the weight in SD 22 and SD 24 (Table 3). The CPUE of flounder and plaice was highest in SD 24 and the CPUE of dab was highest in SD 22. The CPUE of plaice and turbot were low in all SD.

The spatial distribution of cod CPUE showed a clear east-west gradient with highest CPUE in SD 25 (Fig. 2a). For flounder the CPUE was similar high in SD 24 and SD 25 but low in SD 22 (Fig. 2b). Plaice CPUE was highest in SD 24 (Fig. 2c) and dab CPUE was highest in SD 22 (Fig. 2d). The CPUE of turbot was similarly low in all SD (Fig. 2e). 
The discard compositions (\% median of discard a large component in the discard weight. All other species weight) were dominated by cod especially with OTM, in provided a relative discard fraction of less than $10 \%$.

quarter 2, SD 25 and all years but 2008 (Fig. 3a-d). With The relative discard rates of the median catch were TTB, in quarter 1, in SD 24 and in 2008 flounder was also 3.99, 0.76, 0.0, 0.15, and 0.0 for cod, flounder, plaice,
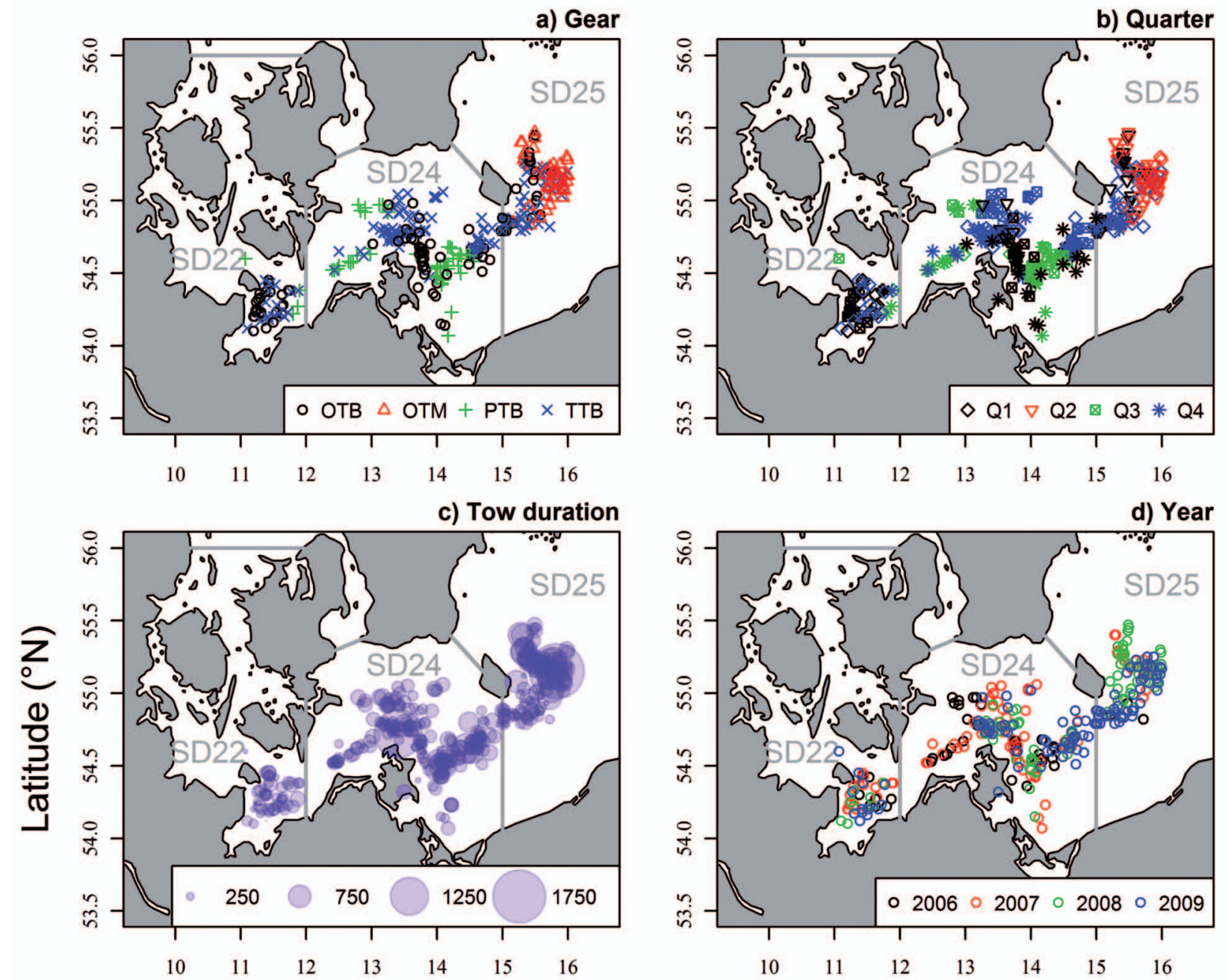

e) Total landings
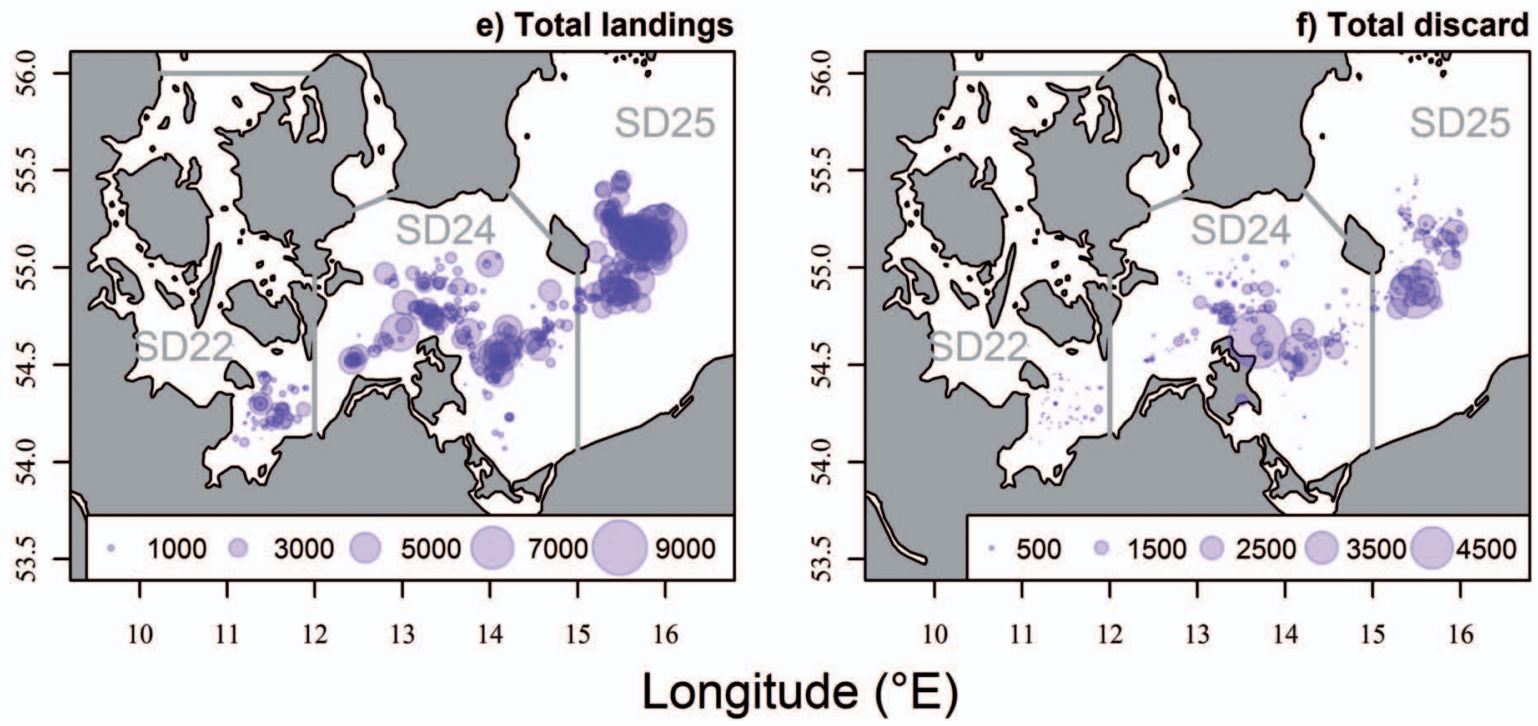

Fig. 1. Distribution of sampled hauls by: a) gear type, b) annual quarter, c) tow duration [min], d) year, e) total landings $[\mathrm{kg}]$, and $\mathrm{f}$ ) total discards $[\mathrm{kg}]$; OTB = otter board bottom, OTM = otter board midwater, PTB = pair trawl bottom, TTB = twin trawl bottom; Note that c), e), and f) are plotted in transparent colours so the intensity of the colour indicates overlap of sampling points while the metric size is expressed by the diameter of the circle 
dab, and turbot, respectively. The relative discard rates of cod were lower for OTB than for all other gears (Table 4). For flatfishes OTM was the gear with the lowest discard rates (Fig. 4a). Grouped by quarter, cod discards were slightly higher in quarter two and three than in quarter one and four (Table 4). The opposite pattern was observed for flatfish species with lowest discard rates occurring in quarter two and three. The discard rate of cod was lower in 2008 when discard rates of flounder were highest (Table 4). For cod discard rates were higher in SD 24 and SD 25 than in SD 22 (Table 4). Flounder, plaice, and dab discard rates were highest in SD 24. The discard rates of turbot were similar between all SD.

The median species-specific discard rates $(\%$ of species catch weight) of cod, flounder, plaice, dab, and turbot were $5.72 \%, 12.90 \%, 0.00 \%, 19.46 \%$, and $0.00 \%$, respectively. The spatial patterns of species-specific discard rates indicate lowest discard rates for cod in SD 22 and SD 25 (Fig. 4a). Flounder and dab had the highest species-specific discard rates in SD 24 and SD 25 (Fig. $4 \mathrm{~b}-\mathrm{e})$, plaice and turbot were mostly discarded in SD 22 and SD 24.

Influence of technical, spatial and temporal factors on catch composition. The nMDS ordination of the haul catch composition and the factors indicates a field of samples between two clusters representing hauls with only cod (aggregation of dots in the lower left) and only flounder (aggregation of dots in the upper left) in the catch (Fig. 5). High landings of cod ordinated with high cod discard, OTM, quarter two, SD 25 and geographical position. The nMDS ordination thus reflected the fisheries in the Bornholm deep during the spawning aggregation of central Baltic cod in spring. The centroid for the landing weights of flounder fell on the opposite side of the cod landings centroid, which indicates that flounder were only landed in large masses when no cod was caught. Flounder discards fell in the same cluster as the discards of other flatfish species, thus the discarding of flatfishes was independent of the target species (cod or flounder).

\section{DISCUSSION}

The results of this study clearly demonstrate that cod is the most important fish targeted by the German Baltic demersal trawl fleet because it is caught in the largest quantities. The Baltic cod fisheries can be divided into two categories: truly demersal fisheries using ground nets (OTB, PTB, or TTB) mostly occurring in SD 22 and SD 24 with high by-catches of non-target species on the one hand and a pelagic cod fishery in SD 25 east of Bornholm, in which by-catches of other species are low. The fisheries in SD 25 target the spawning aggregations of central Baltic cod and thus occur mainly in spring and early summer. During this season vessels between 15 and $26 \mathrm{~m}$ length make their highest profits aiming to fulfil their quota on eastern Baltic cod as soon as possible. Vessels that fulfil

Table 3

Multiple comparisons of median catch per unit effort $\left(\mathrm{kg} \cdot \mathrm{h}^{-1}\right)$ by pair wise Mann-Whitney $U$ tests

\begin{tabular}{|c|c|c|c|c|c|c|}
\hline Factor & Species & $P$ & Factor level 1 & Factor level 2 & Factor level 3 & Factor level 4 \\
\hline \multirow{6}{*}{ 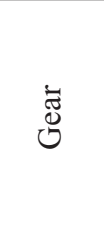 } & & & OTB & OTM & PTB & TTB \\
\hline & Cod & $<0.001$ & $64.29(\mathrm{C})$ & 297.67 (A) & $210.89(\mathrm{~B})$ & $172.62(\mathrm{~B})$ \\
\hline & Flounder & $<0.001$ & $13.52(\mathrm{~A})$ & $0.00(\mathrm{C})$ & 15.19 (A) & $6.18(\mathrm{~B})$ \\
\hline & Plaice & $<0.001$ & $0.50(\mathrm{~B})$ & $<0.00(\mathrm{C})$ & 3.48 (A) & $6.18(\mathrm{~A})$ \\
\hline & Dab & $<0.001$ & $0.70(\mathrm{~B})$ & $<0.00(\mathrm{C})$ & $3.98(\mathrm{~A})$ & $1.32(\mathrm{~B})$ \\
\hline & Turbot & $<0.001$ & $<0.00(\mathrm{~A})$ & $<0.00(\mathrm{~B})$ & $<0.00(\mathrm{~A})$ & $<0.00(\mathrm{~A})$ \\
\hline \multirow{6}{*}{ 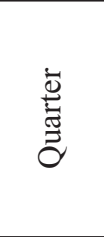 } & & & 1 & 2 & 3 & 4 \\
\hline & Cod & $<0.001$ & $207.11(\mathrm{~B})$ & 337.28 (A) & $139.52(\mathrm{C})$ & 99.91 (C) \\
\hline & Flounder & $<0.001$ & $73.44(\mathrm{~A})$ & 0.36 (D) & $4.60(\mathrm{C})$ & 33.92 (B) \\
\hline & Plaice & $<0.001$ & $4.76(\mathrm{~A})$ & $<0.00$ (D) & $0.25(\mathrm{C})$ & 6.83 (B) \\
\hline & Dab & $<0.001$ & $2.92(\mathrm{~A})$ & $<0.00(\mathrm{C})$ & $0.13(\mathrm{~B})$ & $1.95(\mathrm{~A})$ \\
\hline & Turbot & $<0.001$ & $<0.00(\mathrm{C})$ & $<0.00$ (B) & $<0.00(\mathrm{~B})$ & $0.68(\mathrm{~A})$ \\
\hline \multirow{6}{*}{$\underset{\nabla}{\vec{E}}$} & & & 2006 & 2007 & 2008 & 2009 \\
\hline & Cod & $<0.001$ & $231.06(\mathrm{~A})$ & $130.92(\mathrm{~B})$ & $212.00(\mathrm{~A})$ & $211.16(\mathrm{~A})$ \\
\hline & Flounder & $<0.001$ & 14.20 (B) & $13.27(\mathrm{~B})$ & 40.33 (A) & $5.42(\mathrm{~B})$ \\
\hline & Plaice & $<0.001$ & $5.04(\mathrm{~A})$ & $<0.00(\mathrm{~B})$ & $1.27(\mathrm{~A})$ & $3.36(\mathrm{~A})$ \\
\hline & Dab & $<0.001$ & $7.00(\mathrm{~A})$ & $<0.00(\mathrm{~B})$ & $0.73(\mathrm{~B})$ & 0.49 (B) \\
\hline & Turbot & 0.038 & $<0.00$ & $<0.00$ & $<0.00$ & $<0.00$ \\
\hline \multirow{6}{*}{ 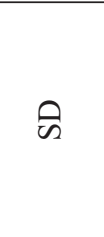 } & & & SD 22 & SD 24 & SD 25 & \\
\hline & Cod & $<0.001$ & 134.25 (B) & $140.35(\mathrm{~B})$ & 306.47 (A) & \\
\hline & Flounder & $<0.001$ & $11.96(\mathrm{~B})$ & 39.94 (A) & $1.46(\mathrm{~B})$ & \\
\hline & Plaice & $<0.001$ & 0.99 (B) & $5.90(\mathrm{~A})$ & $<0.00(\mathrm{C})$ & \\
\hline & Dab & $<0.001$ & $10.35(\mathrm{~A})$ & 1.67 (B) & $<0.00(\mathrm{C})$ & \\
\hline & Turbot & $<0.001$ & $<0.00(\mathrm{~A})$ & $<0.00(\mathrm{~A})$ & $<0.00(\mathrm{~B})$ & \\
\hline
\end{tabular}

OTB = otter trawl bottom, OTM = otter trawl midwater, PTB = pair trawl bottom, TTB = twin trawl bottom; SD = ICES subdivision; The letters in brackets group medians by statistical similarity; Significance of Kruskal-Wallis ANOVA is set in italic font if $P<0.0083$ and 0.0125 due to Bonferroni correction $(0.05 /$ number of tests). 
their quota earlier than others have good chances to get quota shares from vessels which have not yet exhausted their quota. This results in a rush for eastern cod in the first and second quarter. Given the good development of the Eastern
Baltic cod stock (Anonymous 2010), its revenue and current quota regime, this behaviour can be expected to continue.

The high average CPUE of cod in SD 25 indicates that this fishery is highly efficient compared to the fisheries in a) COD

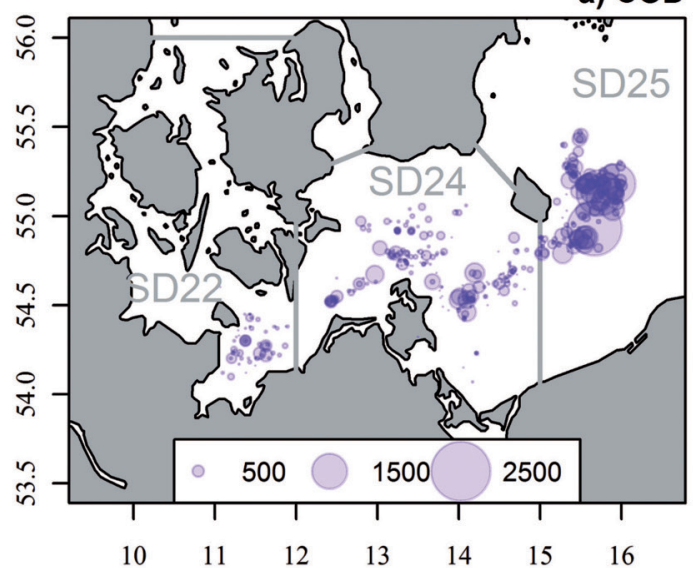

c) PLE

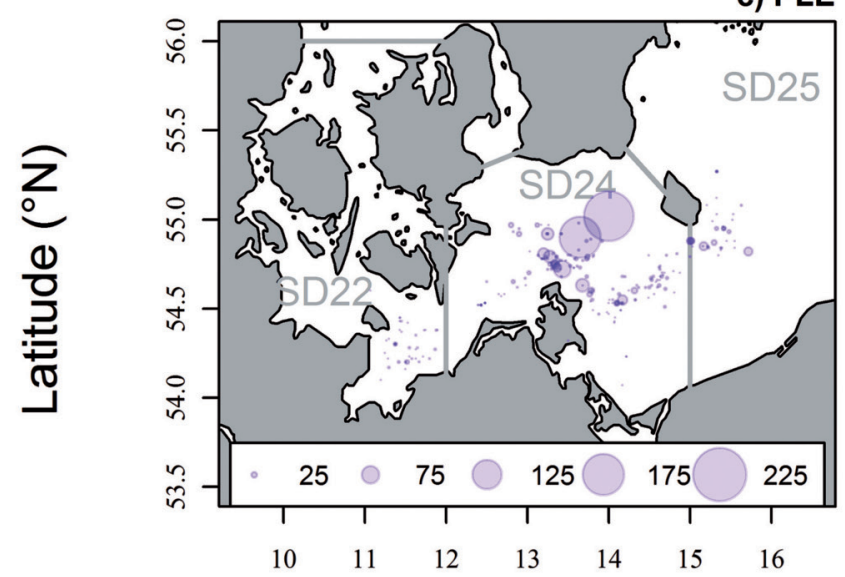

e) TUR

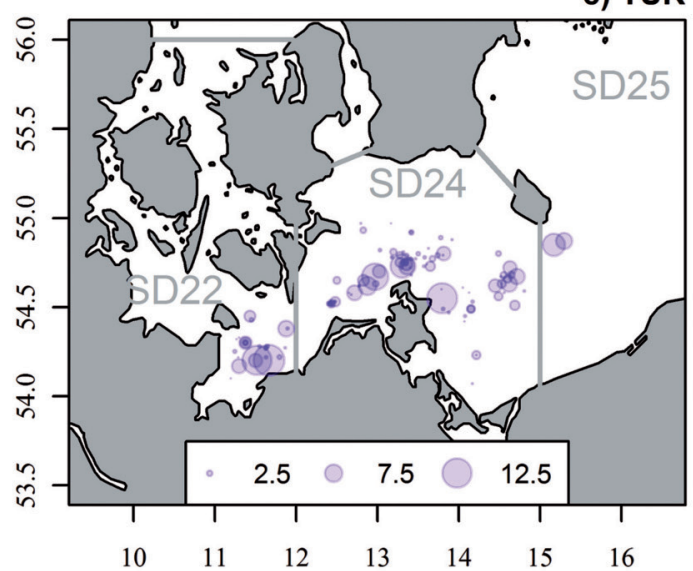

b) FLE

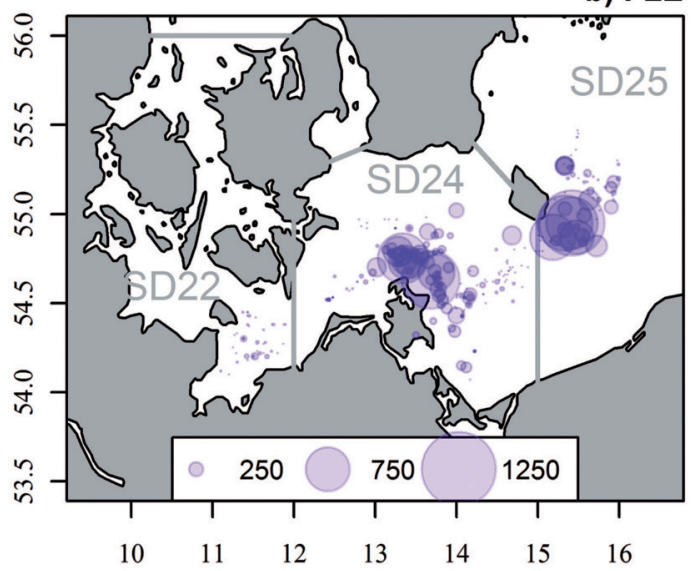

d) DAB

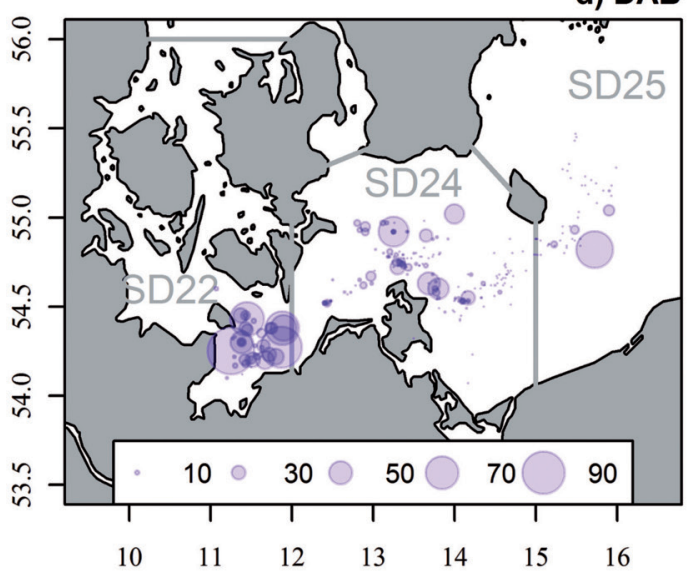

\section{Longitude $\left({ }^{\circ} \mathrm{E}\right)$}

Fig. 2. Spatial patterns of catch per unit effort (CPUE) $\left[\mathrm{kg} \cdot \mathrm{h}^{-1}\right]$ of a) cod, b) flounder, c) plaice, d) dab, and e) turbot; Data are combined for all years; Note that the CPUE are plotted in transparent colours so the intensity of the colour indicates overlap of sampling points while the metric size is expressed by the diameter of the circle 
a)

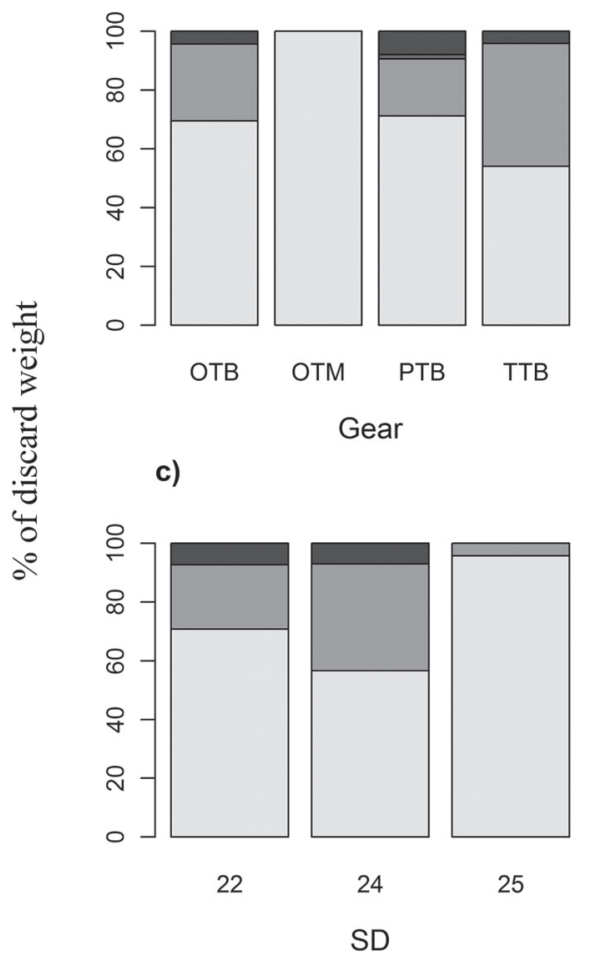

b)

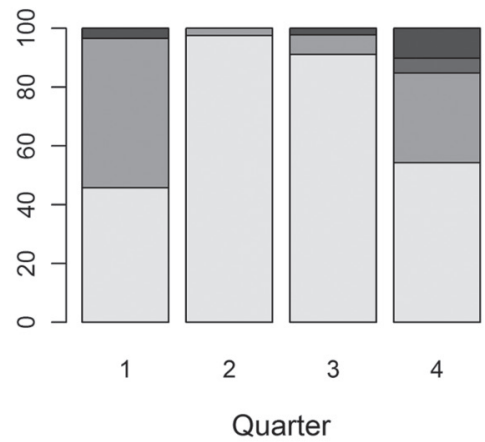

d)

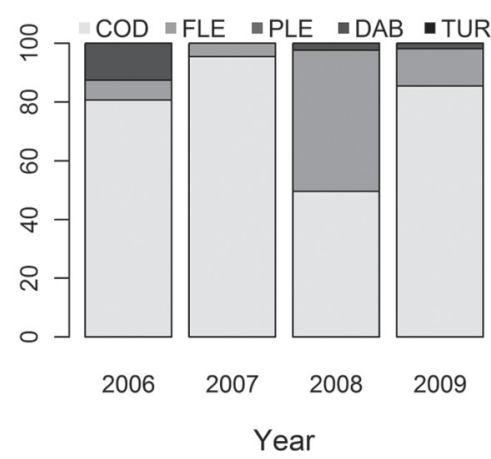

Fig. 3. Composition of relative discard rates by median weights aggregated by a) gear, b) annual quarter, c) ICES subdivision, and d) gear type

Table 4

Multiple comparisons of relative discard rate [\% of total catch] medians by pair wise Mann-Whitney $U$ tests

\begin{tabular}{|c|c|c|c|c|c|c|}
\hline Factor & Species & $P$ & Factor level 1 & Factor level 2 & Factor level 3 & Factor level 4 \\
\hline \multirow{6}{*}{$\begin{array}{l}\dot{\vec{J}} \\
\stackrel{0}{0}\end{array}$} & & & OTB & OTM & PTB & TTB \\
\hline & Cod & $<0.001$ & $2.66(\mathrm{~B})$ & $5.81(\mathrm{~A})$ & $5.31(\mathrm{~A})$ & 4.04 (A) \\
\hline & Flounder & $<0.001$ & 0.57 (B) & $<0.00(\mathrm{C})$ & $1.52(\mathrm{AB})$ & $2.72(\mathrm{~A})$ \\
\hline & Plaice & $<0.001$ & $<0.00(\mathrm{~B})$ & $<0.00(\mathrm{~B})$ & $0.01(\mathrm{~A})$ & $<0.00(\mathrm{~B})$ \\
\hline & Dab & $<0.001$ & 0.11 (B) & $<0.00(\mathrm{C})$ & $0.51(\mathrm{~A})$ & $0.30(\mathrm{AB})$ \\
\hline & Turbot & 0.298 & $<0.00$ & $<0.00$ & $<0.00$ & $<0.00$ \\
\hline \multirow{6}{*}{ 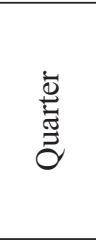 } & & & 1 & 2 & 3 & 4 \\
\hline & Cod & 0.004 & 3.07 (B) & $6.03(\mathrm{~A})$ & $4.30(\mathrm{AB})$ & $3.80(\mathrm{~B})$ \\
\hline & Flounder & $<0.001$ & 3.57 (A) & 0.08 (B) & 0.12 (B) & $1.26(\mathrm{~A})$ \\
\hline & Plaice & $<0.001$ & $<0.00(\mathrm{~B})$ & $<0.00$ (B) & $<0.00$ (B) & $0.24(\mathrm{~A})$ \\
\hline & Dab & $<0.001$ & 0.24 (B) & $<0.00(\mathrm{C})$ & 0.03 (B) & $0.62(\mathrm{~A})$ \\
\hline & Turbot & 0.201 & $<0.00$ & $<0.00$ & $<0.00$ & $<0.00$ \\
\hline \multirow{6}{*}{ 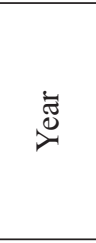 } & & & 2006 & 2007 & 2008 & 2009 \\
\hline & Cod & 0.002 & 4.07 (A) & $3.87(\mathrm{AB})$ & 2.69 (B) & $5.26(\mathrm{~A})$ \\
\hline & Flounder & $<0.001$ & 0.42 (B) & $0.17(\mathrm{~B})$ & $4.68(\mathrm{~A})$ & $0.73(\mathrm{~B})$ \\
\hline & Plaice & 0.003 & $<0.00(\mathrm{~A})$ & $<0.00(\mathrm{~A})$ & $<0.00(\mathrm{~A})$ & $<0.00(\mathrm{~A})$ \\
\hline & Dab & $<0.001$ & $0.64(\mathrm{~A})$ & $<0.00$ (B) & 0.15 (B) & 0.11 (B) \\
\hline & Turbot & 0.176 & $<0.00$ & $<0.00$ & $<0.00$ & $<0.00$ \\
\hline \multirow{6}{*}{$\ddot{\approx}$} & & & SD 22 & SD 24 & SD 25 & \\
\hline & Cod & $<0.001$ & $2.30(\mathrm{~B})$ & $4.05(\mathrm{~A})$ & $4.82(\mathrm{~A})$ & \\
\hline & Flounder & $<0.001$ & 0.34 (B) & $1.9(\mathrm{~A})$ & $0.24(\mathrm{~B})$ & \\
\hline & Plaice & $<0.001$ & $<0.00(\mathrm{~B})$ & $<0.00(\mathrm{~A})$ & $<0.00(\mathrm{~B})$ & \\
\hline & Dab & $<0.001$ & 0.17 (B) & $0.52(\mathrm{~A})$ & $<0.00(\mathrm{C})$ & \\
\hline & Turbot & 0.153 & $<0.00$ & $<0.00$ & $<0.00$ & \\
\hline
\end{tabular}

$\mathrm{OTB}=$ otter trawl bottom, OTM = otter trawl midwater, $\mathrm{PTB}=$ pair trawl bottom, TTB $=$ twin trawl bottom; SD $=\mathrm{ICES}$ subdivision; The letters in brackets group medians by statistical similarity; Significance of Kruskal-Wallis ANOVA is set in italic font if $P<0.0083$ and 0.0125 due to Bonferroni correction $(0.05 /$ number of tests). 
SD 22 and SD 25. The usage of OTM is very specific and damage to benthic habitats (mussel beds and soft sediments) discards of flatfishes are low with this gear type. Thus the is negligible making pelagic fisheries a preferable method to OTM cod fisheries in SD 25 can be considered to have com- demersal fishing. Currently, the situation of the central Baltic paratively low environmental impacts. Furthermore, the cod stock is improving (Anonymous 2010) and the demersal

a) COD

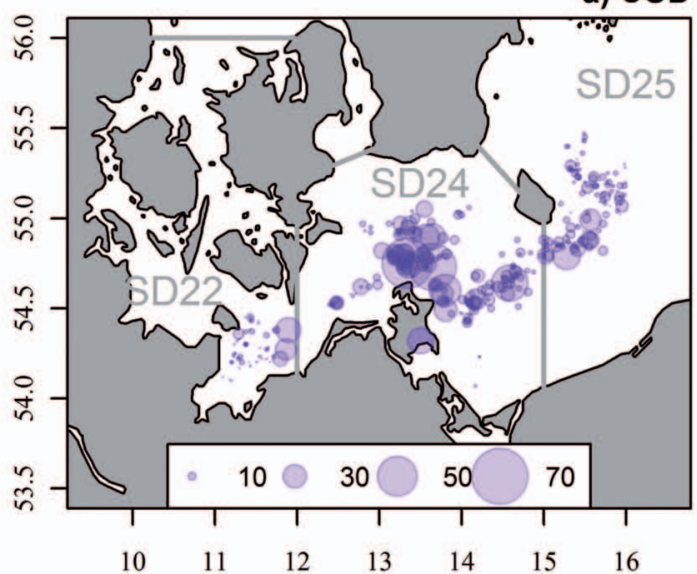

c) PLE

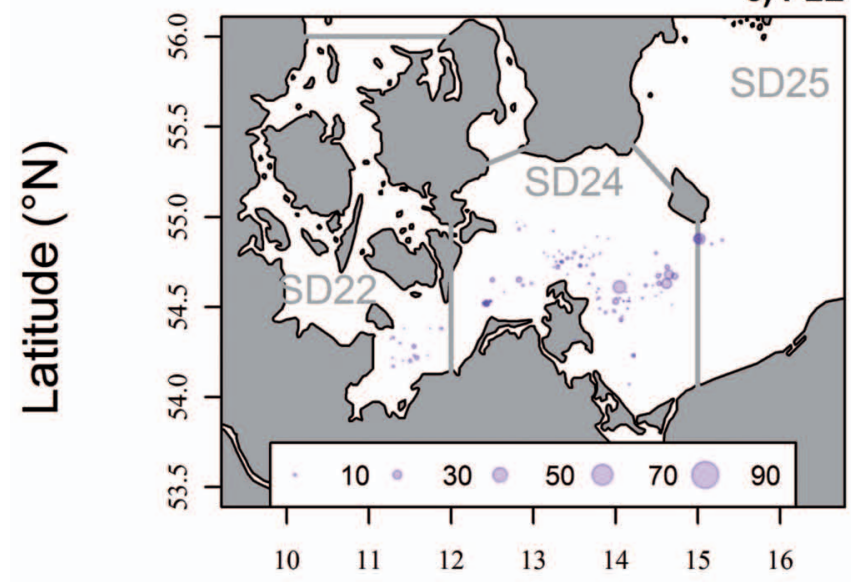

e) TUR

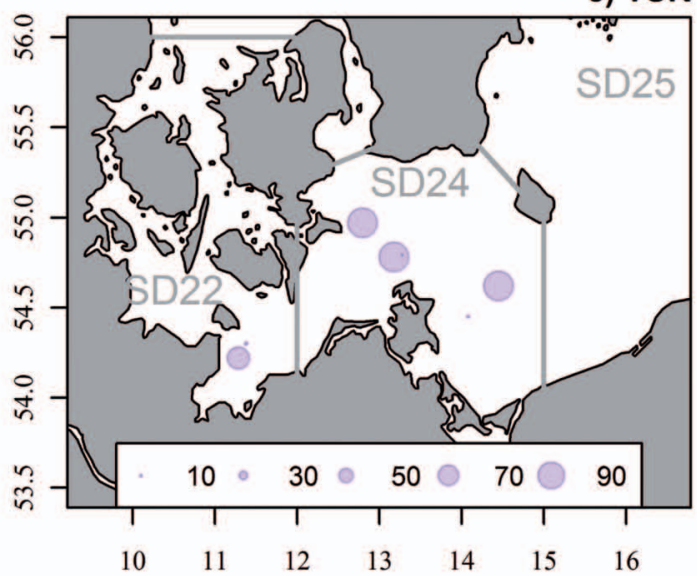

b) FLE

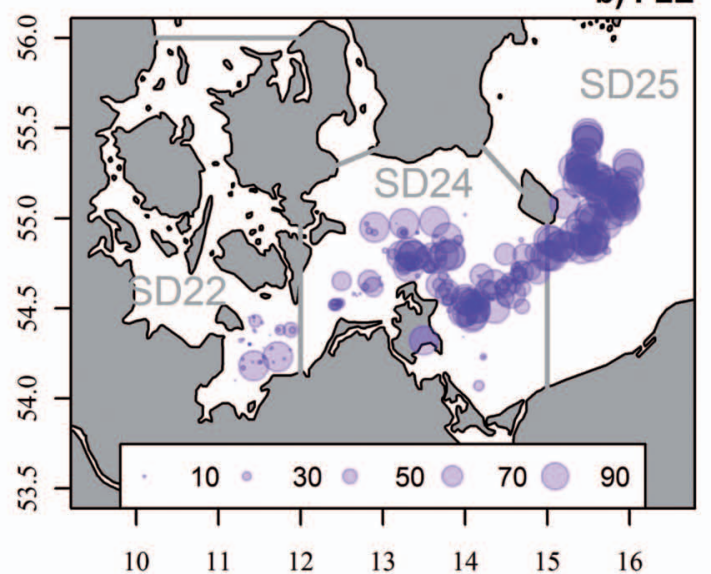

d) DAB

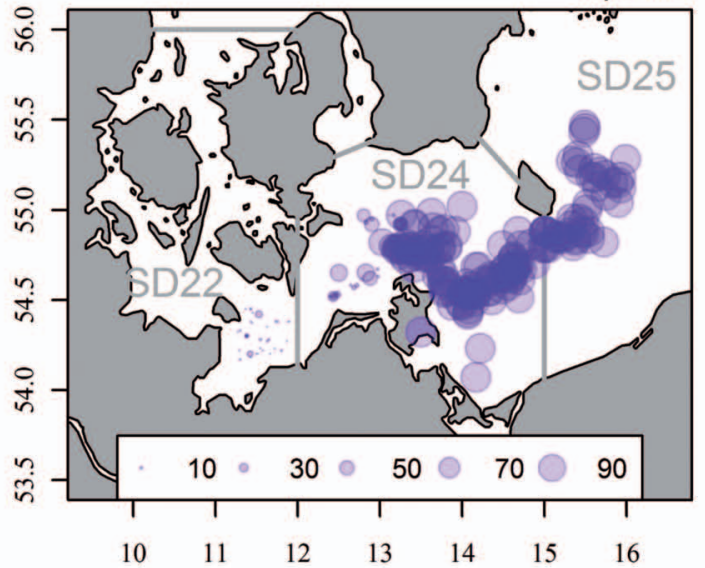

\section{Longitude $\left({ }^{\circ} \mathrm{E}\right)$}

Fig. 4. Spatial patterns of species-specific discard rates [\% of catch weight by species] of a) cod, b) flounder, c) plaice, d) dab, and e) turbot; Data are combined for all years; Note that the discard rates are plotted in transparent colours so the intensity of the colour indicates overlap of sampling points while the metric size is expressed by the diameter of the circle 
Danish cod fisheries has been certified by the Marine Stewardship Council. Under these circumstances German vessels using pelagic gears in SD 25 have a similar potential.

The implemented closure in SD 25 from July to August (Kraus et al. 2009) and the TAC limitation on the eastern cod stock forces the German fishermen to catch cod in SD 22 and SD 24 during summer and fall. During this season, relatively high catches can be obtained, but usually catches are lower than during spring in SD 25.

The decision to land or to discard flounder depended on the amount of caught cod, the expected duration of the trip, the location and their expected landing value. Variable discarding practices of less valuable fish has been reported for Scottish vessels in the North Sea (Stratoudakis et al. 1998) and reflect the economic necessities of fishermen. In the Baltic, flounder become a primary target of German fishermen only during summer, when catch opportunities for cod are reduced. During this season fishermen stay close to their home ports and try to cover their maintenance costs with mixed catches of cod and flatfishes (Strehlow 2010).

The analysis of sampled catch compositions combined by several years allows the comparison against other effort estimations. Studies by Pedersen et al. (2009a, b) and Fock (2008) used vessel monitoring (VMS) data from 2006 to analyze the effort distribution in the German Exclusive Economic Zone (EEZ) of the Baltic Sea. These studies identify the Mecklenburg Bight (SD 22/24) and the Arkona Sea Northeast of the island of Rügen (SD 24) as the main areas for otter trawling. This is consistent with the observed distribution of sampled hauls of the present study. However, because Fock (2008) and Pedersen et al. (2009a, b) confined their analysis to the German EEZ, the importance of the Bornholm deep for the German trawl fleet is not considered. However, the revenue of a fishing year and thus the fishing incentives and behaviour of the German fleet in SD 22 and SD 24 are strongly influenced by fishing opportunities in SD 25. Any measures that affect the eastern Baltic cod stock will therefore have implications for the western Baltic fisheries alike, as fishermen will try to adjust their catch in SD 22 and SD 24 to the opportunities in SD 25.

The effort estimations based on VMS data do not indicate the areas of highest catches and discards. According to previous (Fock 2008, Pedersen et al. 2009a, b) the

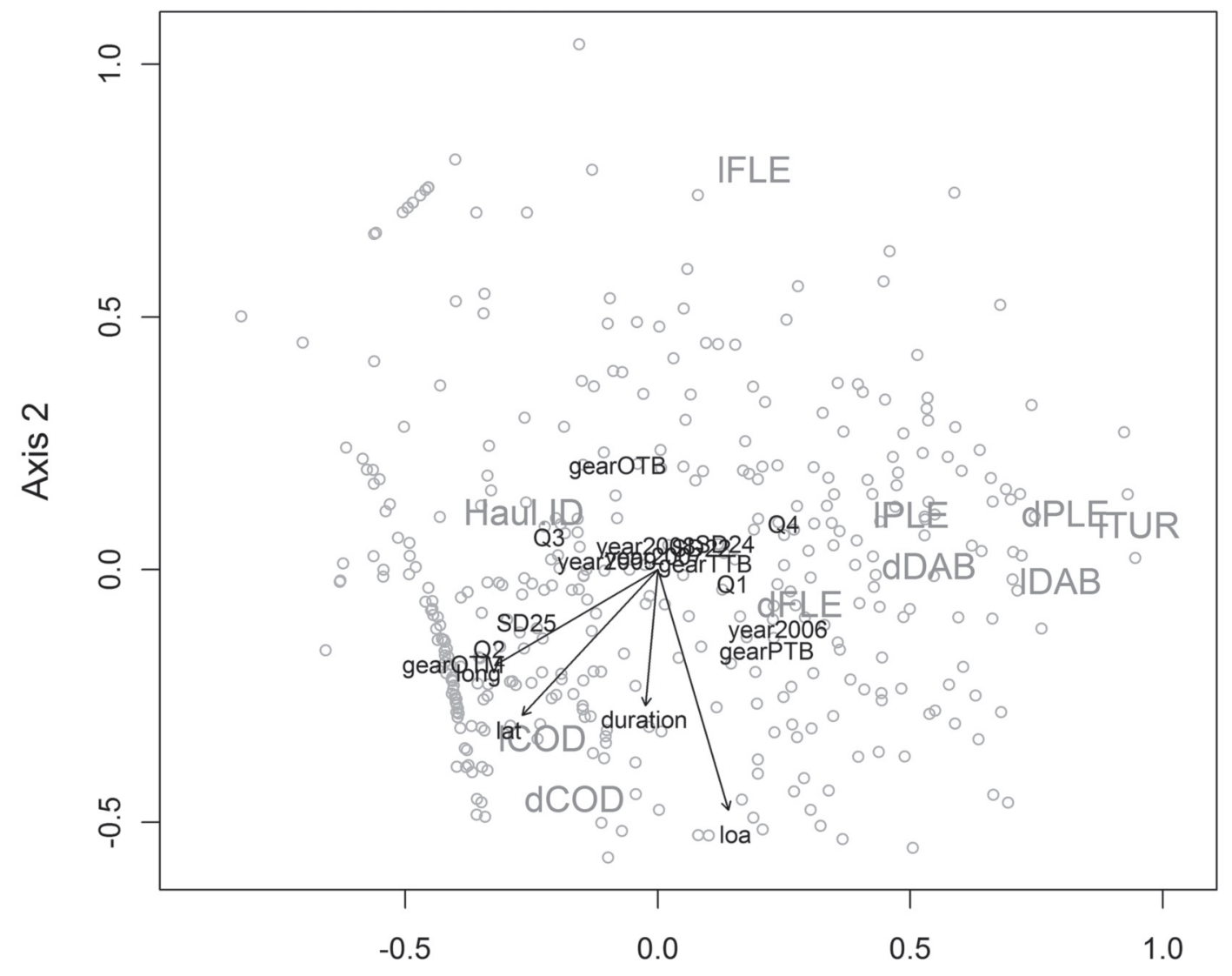

Axis 1

Fig. 5. Multivariate ordination of catch composition by weight by non-metric multidimensional scaling (nMDS); COD $=$ Baltic cod, FLE = flounder, PLE = plaice, DAB = dab, TUR = turbot, prefixes 'd' and ' 1 ' mean discard and landing, respectively, $\mathrm{Q}=$ annual Quarter, loa = length of vessel, lat = latitude, long = longitude, OTB = otter board bottom trawl, OTM = otter board mid water trawl, PTB = pair trawl bottom, TTB = twin trawl bottom; Haul.ID = haul identifier ranging from $1 / 12$ to 1 ; Grey dots represent sampled hauls $(n=370)$, black arrows represent continuous predictors; Grey labels without arrow indicate categorical predictors 
trawling effort in SD 22 was high in 2006, but the observer data implicates that the total landings and discards in this subdivision were low. In SD 22 the fisheries is operated by small vessels of which many are smaller than 12 $\mathrm{m}$. These fisheries seem to land a higher proportion of their catch and thus produce less discard even when using ground-touching gear. This may be due to the fact that relatively more fish is retained and sold to local consumers.

The comparison of VMS effort estimation and the present study allows scrutinizing the DCF sampling scheme. Contrary to Pedersen et al. (2009b) and Fock (2008), this study did not observe fishing operations north-west of the Island of Fehmarn in the Kiel Bight implying a sampling gap in the north-western part of the Baltic Sea. This gap results from several reasons:

1. On-board observers are more likely to access larger vessels which operate from only three harbours (Heiligenhafen, Burgstaaken, and Sassnitz);

2. Sampling emphasize was put on trips with high catches, to fulfil the quantitative sampling requirements of the DCF and thus biased on vessels fishing in SD 24 and SD 25;

3. The on-board observers start from Rostock and may be more likely to reach adjacent harbours in SD 24;

4. Lack of compliance or knowledge amongst German captains about the obligations of the DCF. Especially the skippers of smaller vessels are unaware of the DCF or will not accept observers on board due to safety reasons. The current sampling coverage of the German Baltic DCF is therefore neither random nor even for all métiers (see also Benoit and Allard 2009), but new technological advances such as video surveillance or self-sampling agreements may improve the sampling coverage and provide alternative methods to obtain information on the catch composition of under sampled métiers (Kindt-Larsen et al. 2011).

Zeller et al. (2011) criticize the intransparency of data reporting and aggregation within the framework of the Common European Fisheries Policy (CFP). According to their study the volume of fisheries removals is constantly underestimated due to illegal fishing, discarding and lack of management of recreational fisheries. Due to confidential agreements and inaccessibility of reports, data on unallocated catches is not readily available to stakeholders outside national institutes and ICES working groups. Though many of the information from this study can be found in the national annual reports of the DCF, which have to be accessible through national web portals, this data source is not yet well known to decision makers and non-scientific stakeholders. The focused publication of DCF sampling results should therefore widen the awareness of the national sampling programs (Ulleweit et al. 2010).

The information on the distribution of fishing operations and catches will support future management decisions within marine spatial planning schemes and the ecosystem approach to fisheries (Garcia et al. 2003, Kempf 2010), which is implemented within the European Marine policy (Anonymous 2008b). Identifying hot spots of fishing effort, catch, and discarding will help to evalu- ate the impacts of spatial measures on the catch opportunities of German fishermen. Changes in the spatial use of currently available fishing grounds are to be expected within the implementation of the Natura 2000 process (Pedersen et al. 2009a, b, Fock et al. 2011). In the planning of marine uses such as offshore wind farming and the construction of new pipelines their cumulative impacts on fishing are often overlooked (Berkenhagen et al. 2010). A comprehensive documentation on the distribution of fleets before the implementation of spatial measures as provided by this study will facilitate to assess changes in the fleet distribution in relation to other marine uses.

\section{ACKNOWLEDGMENTS}

This study was partly funded by the European Union within the data collection framework (EC, 2000). We are thankful to all on-board observers who contributed with their effort and determination to the present data set, namely Steffen Hagemann, Andres Velasco, Titus Rohde, and Tom Jankiewicz. We also thank all fishermen and vessel owners who allowed placing observers on board.

\section{REFERENCES}

Anonymous 2004. Commission regulation (EC) No 1581/2004 of 27 August 2004 amending Regulation (EC) No $1639 / 2001$ establishing the minimum and extended Community programmes for the collection of data in the fisheries sector and laying down detailed rules for the application of Council Regulation (EC) No 1543/2000. Official Journal of the European Union L 289: 6-53.

Anonymous 2005. Council regulation (EC) No 2187/2005 of 21 December 2005 for the conservation of fishery resources through technical measures in the Baltic Sea, the Belts and the Sound, amending Regulation (EC) No 1434/98 and repealing Regulation (EC) No 88/98. Official Journal of the European Union L 349: 1-23.

Anonymous 2008a. R: A language and environment for statistical computing. R Foundation for Statistical Computing, Vienna, Austria. ISBN 3-900051-07-0. http:/www.R-project.org.

Anonymous 2008b. Directive 2008/56/EC of the European Parliament and of the Council of 17 June 2008 establishing a framework for community action in the field of marine environmental policy (Marine Strategy Framework Directive). Official Journal of the European Union L 164: 19-40.

Anonymous 2010. Report of the ICES Advisory Committee, 2010. ICES Advice 2010. Book 8 Baltic Sea. ICES, Copenhagen.

Benoît H.P., Allard J. 2009. Can the data from at-sea observer surveys be used to make general inferences about catch composition and discards? Canadian Journal of Fisheries and Aquatic Sciences 66 (12): 2025-2039. DOI: 10.1139/f09-116

Berkenhagen J., Döring R., Fock H.O., Kloppmann M.H.F., Pedersen S.A., Schulze T. 2010. Decision bias in marine spatial planning of offshore wind farms: Problems of singular versus cumulative assessments of economic impacts on fisheries. Marine Policy 34 (3): 733-736.

DOI: 10.1016/j.marpol.2009.12.004 
Clarke K.R., Warwick R.M. 2001. Change in marine communities: An approach to statistical analysis and interpretation. 2nd edn. PRIMER-E, Plymouth.

Cotter A.J.R., Pilling G.M. 2007. Landings, logbooks and observer surveys: improving the protocols for sampling commercial fisheries. Fish and Fisheries 8 (2): 123-152. DOI: $10.1111 /$ j.1467-2679.2007.00241.x

Fock H.O. 2008. Fisheries in the context of marine spatial planning: Defining principal areas for fisheries in the German EEZ. Marine Policy 32 (4): 728-739.

DOI: $10.1016 /$ j.marpol.2007.12.010

Fock H.O., Kloppmann M., Stelzenmüller V. 2011. Linking marine fisheries to environmental objectives: a case study on seafloor integrity under European maritime policies. Environmental Science and Policy 14 (3): 289-300. DOI: $10.1016 /$ j.envsci.2010.11.005

Garcia S.M., Zerbi A., Aliaume C., Do Chi T., Lasserre G. 2003. The ecosystem approach to fisheries. Issues, terminology, principles, institutional foundations, implementation and outlook. FAO Fisheries Technical Paper. No. 443. FAO, Rome.

Jennings S., Kaiser M.J., Reynolds J.D. 2001. Marine fisheries ecology. Blackwell Science, Oxford.

Kempf A. 2010. Ecosystem approach to fisheries in the European context-history and future challenges. Journal of Applied Ichthyology 26 (Suppl. s1): 102-109. DOI: $10.1111 /$ j.1439-0426.2010.01451.x

Kindt-Larsen L., Kirkegaard E., Dalskov J. 2011. Fully documented fishery: a tool to support a catch quota management system. ICES Journal of Marine Science 68 (8): 1606-1610. DOI: 10.1093/icesjms/fsr065

King M. 2007. Fisheries biology, assessment and management. Blackwell Publishing, Oxford.

Kraus G., Pelletier D., Dubreuil J., Möllmann C., Hinrichsen H.-H., Bastardie F., Vermard Y., Mahévas S. 2009. A modelbased evaluation of marine protected areas: the example of eastern Baltic cod (Gadus morhua callarias L.). ICES Journal of Marine Science 66 (1): 109-121.

DOI: $10.1093 /$ icesjms/fsn166

Mehner T., Diekmann M., Brämick U., Lemcke R. 2005. Composition of fish communities in German lakes as related to lake morphology, trophic state, shore structure and human-use intensity. Freshwater Biology 50 (1): 70-85. DOI: 10.1111/j.1365-2427.2004.01294.x

Minchin P.R. 1987. An evaluation of the relative robustness of techniques for ecological ordination. Plant Ecology 69 (1-3): 89-107.

DOI: $10.1007 / \mathrm{BF} 00038690$

Oksanen J., Blanchet F.G., Kindt R., Legendre P., Minchin P.R., O'Hara R.B., Simpson G.L., Solymos P., Stevens M.H.M., Wagner H. 2011. Package 'vegan'. http://cran. r-project.org/web/packages/vegan/vegan.pdf.

Pedersen S.A., Fock H., Krause J., Pusch C., Sell A.L., Böttcher U., Rogers S.I., Sköld M., Skov H., Podolska M., Piet G.J., Rice J.C. 2009a. Natura 2000 sites and fisheries in German offshore waters. ICES Journal of Marine Science 66 (1): $155-169$.

DOI: $10.1093 /$ icesjms/fsn193

Pedersen S.A., Fock H.O., Sell A.F. 2009b. Mapping fisheries in the German exclusive economic zone with special reference to offshore Natura 2000 sites. Marine Policy 33 (4): 571-590.

DOI: 10.1016/j.marpol.2008.12.007

Stelzenmüller V., Lee J., Garnacho E., Rogers S.I. 2010. Assessment of a Bayesian Belief Network-GIS framework as a practical tool to support marine planning. Marine Pollution Bulletin 60 (10): 1743-1754.

DOI: 10.1016/j.marpolbul.2010.06.024

Stransky C., Berkenhagen J., Berth U., Ebeling M., JiménezKrause J.D., Panten K., Schultz N., Ulleweit J., Velasco A., Wern W., Zimmermann C. 2008. Nationales Fischereidatenerhebungsprogramm: Aktivitäten und Ausblick. Informationen aus der Fischereiforschung 55: 5-14.

DOI: 10.3220/Infn55_5-14_2008

Stratoudakis Y., Fryer R.J., Cook R.M. 1998. Discarding practices for commercial gadoids in the North Sea. Canadian Journal of Fisheries and Aquatic Sciences 55: 1632-1644. DOI: $10.1139 /$ cjfas-55-7-1632

Strehlow H. 2010. The multiannual management plan for cod in the Baltic Sea: reactions and sentiments in two German fishing communities. ICES Journal of Marine Science 67 (9): 1963-1971. DOI: $10.1093 /$ icesjms/fsq127

Suuronen P., Tschernij V., Jounela P., Valentinsson D., Larsson P.-O. 2007. Factors affecting rule compliance with mesh size regulations in the Baltic cod trawl fishery. ICES Journal of Marine Science 64 (8): 1603-1606.

DOI: 10.1093/icesjms/fsm124

Ulleweit J., Stransky C., Panten K. 2010. Discards and discarding practices in German fisheries in the North Sea and Northeast Atlantic during 2002-2008. Journal of Applied Ichthyology 26 (Suppl. s1): 54-66. DOI: $10.1111 /$ j.1439-0426.2010.01449.x

Wienbeck H., Herrmann B., Moderhak W., Stepputtis D. 2011. Effect of netting direction and number of meshes around on size selection in the codend for Baltic cod (Gadus morhua). Fisheries Research 109 (1): 80-88.

DOI: 10.1016/j.fishres.2011.01.019

Zeller D., Rossing P., Harper S., Persson L., Booth S., Pauly D. 2011. The Baltic Sea: Estimates of total fisheries removals 1950-2007. Fisheries Research 108 (2-3): 356-363.

DOI: $10.1016 /$ j.fishres.2010.10.024

Received: 25 November 2011

Accepted: 7 December 2011 Published electronically: 31 December 2011 